\title{
SEMANTIC AMBIGUITIES AND CLASSIFICATION STRUGGLES IN THE POST-SOCIALIST INFORMAL MEDICAL ECONOMY
}

\section{CRISTINE PALAGA ${ }^{1}$}

\begin{abstract}
In this paper I will engage in a process of highlighting the way in which liberal and, later, neoliberal political agendas regulate and establish formal semantic registers in the field of medical informal economy within the Romanian public healthcare system. How accurate is the legalistic approach, which classifies any extra-payment as a bribe? Despite the questionable legal status, the voluntary informal economy acquires the role of establishing bridges at human level between doctor and patient. Far from pleading to accept the conditioning of the medical act by an additional payment from patients or their family members, facts that obviously fall within the scope of illegality, I claim that the labels of "corruption", "bribe", "informal payment" cannot be correctly applied to the whole phenomenon of informal exchanges. Moreover, the gifts offered as a form of gratitude or to tame the "medical gaze" even have a role of social link between doctor and patient, helping to bind an unwritten human contract between the two who, in fact, are victims of the same system and its political decision-makers.
\end{abstract}

Keywords: informal payments, gift vs. commodity, medical systems, power relations, formalising common-sense on informality, symbolic power, strategic narratives

Motto: Social science works with realities already named, already classified, bearing proper names and common names, titles, signs, logos. In order not to risk adopting, without realising it, constitutive acts whose logic and necessity they ignore, it must take as its object the social operations of appointment and the rites of establishment by which these acts are performed. (Bourdieu, 2012:135).

\section{Circuits of exchange: Gift, commodities and hybrid hypostases}

Social anthropology differentiates between two types of exchange in human societies: gift-based relationships (gift relations) and commodity-based relations (commodity relations, Mauss, 1954). This distinction is made according

1 Sociology Department, Babeș-Bolyai University Cluj-Napoca, e-mail: palagacristine@gmail.com 
to the degree of sociability involved in the exchange; thus, the gift belongs to the sphere of personal relations, while the commodity is assigned to impersonal, commercial relations.

For Mauss, the gift is a label of pre-modern societies, while commoditybased exchange is typical of a modern societal organisation. Currently, it is believed that the gift and the commodity can exist simultaneously in the same society, giving up the attribution of gift-based relationships to cultures that precede modernity (Gregory, 1980). Reiterating the distinction "gift-commodity", Gregory (1980; 1982 apud. Rus, 2008) radicalised the Maussian model, opposing the gift to commodity. Commodity is a product of labor, being intended for exchange through a sale-purchase process. The exchange of commodity has a deeply impersonal character, and the transaction does not require long-term personal relationships, being exclusively dependent on economic rationality and obtaining added value.

In the capitalist social system, people are forced to think of exchange relations as a direct expression of the material properties inherent to money and goods. In his critical analysis of the capitalist system of production, Karl Marx (2013 [1867]) calls this optical defect "commodity fetishism": the inability of individuals to think of commodities and money as things "that are inherently full of social, power, and life." (Lewin \& Morris, 1977: 173). Basically, this is because the economic or social production relations in such systems are very complex and very indirect, and people barely feel that they are part of an interdependent network of peers who essentially work for each other (idem). Commodities can be traded without creating lasting relationships between the originator and the recipient. On the contrary, gifts maintain a minimal connection with the person initiating the exchange by transferring its identity to the recipient of the exchange. The commodities are exchanged without involving residual obligations and relationships between the persons involved (Gregory, 1982), but the gift is permanently linked to the one who offers it, creating the obligation of reciprocity (Mauss, 1954). The gift creates an asymmetry in the relationship, forcing a "counter-gift" (Mauss, 1954; Adloff, 2006).

Transgressing the antagonism between gift and commodity, accused of betraying a gullible nostalgia for the social altruism of traditional cultures, Arjun Appadurai (1986) argues that gift- based exchange does not differ radically from the exchange of commercial items. Anthropological writings have exaggerated the contrast between gift and commodity, subscribing to a tendency to romanticise so-called primitive societies and end up marginalising the self-interested nature of trade. Appadurai does not believe in the usefulness of the gift- commodity antagonism, as objects produced as commodity can be traded as gifts and vice versa. Commodity-based or gift-based exchanges are not two mutually exclusive forms, but two ideal types of exchange, the analysis of the context of exchange (social and political) proving to be the only manoeuvre capable of achieving the 
gift-commodity distinction (Appadurai, 1986: 11). In an attempt to open a broad discussion on the deviations and inaccuracies that have been perpetuated and deepened in the post-socialist health system, the anthropologist of Romanian origin Sabina Stan, claims that neither commodities nor commercial articles are traded on the Romanian public health services market and no gifts also ("neither commodities, nor gifts", Stan, 2012: 65), the two being in a strange coexistence.

Any exchange, whether formal or informal, is a dyadic transaction between two stakeholders, being organised around the idea of balance, of parity in gain (Parry \& Bloch, 1989:454). These transactions take the form of actions, motivated by the promise of what they can change for the benefit of the agents involved in the exchange. It would be naive to believe that the gift is a result of the generosity of individuals; similar to impersonal exchanges, and the gift involves a selfish calculation. If the gift hides a selfish interest, its fundamental feature cannot be identified in the motivation of the giver. The key word that distinguishes between commodity and gift is "to hide". It is not the contradiction between the apparent gratuitousness and the obligation of reciprocity that is essential to the nature of the gift, but the observance of those social forms that describe it as distinct from the payment of services, countertop, bribe or informal payment (Smart, 1993). The distinct character of the gift is constituted by an act of "misrecognition" (Bourdieu, 1977), a subtle approach to symbolic disguise, in which the way of offering is so constituted as to make it possible to deny the practical nature of the gift. "Without this will of non-recognition, (...) the intention to force reciprocity becomes immediately apparent and the gift is no longer what it claims to be" (Bourdieu 1977: 5-6). Without this self-deception, collectively approved and supported, the symbolic exchange of gifts could not take place (Bourdieu, 1977: 6). When the purpose of giving a gift becomes obvious, social relationships become endangered. Giving up the game of concealing intent "disregards and offends" (Mauss, 1954: 36). Informal exchanges in the post-socialist health system are not limited to payments for services, because the doctor does not want his services to be simply paid for, he wants the recognition of professional quality. He is not a worker among other workers, his expertise is not simply for sale.

Thus, the manner of giving a gift by the patient follows a standardised ritual, a twisted game, which succeeds when the performance is not interpreted as manipulative. The gift-based exchange relationship initiated by the patient conceals a "fair payment", a compensatory act designed to alleviate the frustration generated by the doctor's financial and social expectations and what the public service may cover. Knowing that the intent to oblige for a counter-gift must seem stripped of social or personal considerations (Mauss, 1954; Gregory, 1982), the patient pays close attention to the form and context in which the gift is offered. The gift is not independent of the absence of practical awareness of the gesture, of the instrumental purpose, but of the need to exclude from performance this practical dimension (the need to non-explicit). Behaviour is conditioned by "the 
belief that interpersonal utility is feasible in the context of bilateral exchange" (Bell, 1991:156). By accepting the gift, the recipient - a member of the medical team - becomes obliged to return the gesture. The expected counter-gift differs from patient to patient, but the latent purpose of giving and accepting "attention" is to create and crystallise the social relationships that are generated between patients, their families, and the medical team. Moreover, the gift retains the social identity of the giver, imposing this identity on the recipient. We take part in a series of conversions that occur between economic and non- economic (Bourdieu, 1986), the monetary economy being transformed into a moral economy.

Gifts create reciprocal relationships between the giver and the recipient, the economic value being subordinated to a moral purpose, that of producing a sense of familiarity, of cementing social relations. It is also pivotal to understand that the gift is an instrument aimed at gaining social capital (Smart, 1993). Social capital consists of claims to reciprocate, and the gift is that resource that guarantees entry into a network of relationships (Bourdieu, 1986). The resulting connections and obligations are the product of investments that "aim at shaping or reproducing social relations" (Bourdieu, 1986: 249). In this perspective, exchange is "part of a system of practices in which participants express, preserve, loose and gain positions in the sphere of social value" (Gudeman, 2001:89-90 apud. Stan, 2012:66): the need to express, the need to engage in informal practices is felt by those in uncertainty on the background of poor health, medical staff whose reciprocity is always reactivated gains and retains its professional value. Patients also gain, because the gift restores the annulled social value in the context of an illness by reducing the being to a pathology, and those unable to reproduce the cycles of exchange terribly loose. The logic of the gift is performative; it creates social and moral relations between the parties involved in reciprocity. The really negative side of the scope of the gift and counter-gift circuit derives from the possible latency of professional expertise and the moral forum where some healthcare professionals are stationed in the absence of stimulation of reciprocity. Informal practices take place in the context of power relations that marginalise, stratify and exclude (Zerilli, 2013), and participants have no choice and, in order to maintain their "social right" to health, engage in these exchanges. Those lacking resources are excluded or condemned to benefit from leftovers, from the little that remains undivided as a result of assembling some energies, preferences, obligations and sensibilities.

\section{The politicisation and incrimination of "giving / receiving" in the field of post-1990 medical informality}

The plethora of articles, old or recent, whose stake is the definition and taxonomy of informal medical payments (Lomnitz, 1988; Ensor \& Savelyeva, 1998; Lambertini, 1999; Thompson \& Witter, 2000; Balabanova \& McKee, 2002; Ensor, 
2004; Sharma, 2005; Gaal et al., 2006; Savedoff, 2006; Lewis, 2000; 2007; Liaropoulolos, et. al., 2008, Vladescu et al., 2008; Stepurko, 2010; Stan, 2012; Baji, 2012; Palaga, 2015; Williams et al., 2016; Najar et al., 2017) avoids questioning the economic strategies and specific political agendas that dictate the use of one meaning to the detriment of another. The importance of the targeted choice of a certain definition of work for those payments made outside the institutionalised channels should not be underestimated, the practical consequences of establishing a discursive order on the informal medical economy being substantial. The classifications and attributes given by the media and the political class to the phenomenon of informal payments have the role of drawing the coordinates through which the public relates to this practice, dictating and forming opinions and behaviours among social actors. The legal implications of payments and public grids marching on the disavowal of the professional prestige of healthcare professionals requesting or accepting informal exchanges are essential in standardising the perception of the informal medical economy.

In the following lines, the analytical thread aims to deconstruct the political process of imagining one of the most pressing problem the Romanian health system is facing today: the corruption that revolves around informal payments. In addition to the exercise of identifying when the suppression of the informal medical economy becomes a leitmotif of the system reform requirements, I propose to make an analysis of the different positions that government decisionmakers belonging to parties of different political orientation (a political left and right) adopts when it comes to managing an entire economy that takes place in the extension of the one regulated at the formal level.

The political, economic and social permutations that opened the last decade of the twentieth century announced an indispensable set of reforms aimed at stabilising Romanian society and placing it in the immediate vicinity of a democratic organisation. The reformist enthusiasm permeated mainly the system of medical services. The need to restructure the financing flows and the form of organisation of the entire Romanian health system since the early 1990s was highlighted by appealing to the narrative of "the state as the worst administrator". During this period, informal payments are not even mentioned in the reform requirements, the focus of criticism on the health system being the hospital infrastructure, the main resource consumer of this sector. It describes a huge health system, insufficiently equipped technologically and over- accessed, even in the absence of medical justifications. The reform measures focus on streamlining health services by reducing the maximum capacity to process medical cases, followed by a broad process of administrative decentralisation and encouraging private equity participation in the delivery of health services. It is important to mention that during the designated period, payments from the health system are part of the general diathesis of informality, along with most of the interactions between the individual and state agencies. The reform 
grids have been drafted and implemented under the strict supervision of international actors such as the World Health Organisation, the World Bank and the United States Agency for International Development. One of the first reports meant to diagnose the problems of the Romanian health system, in the context of the transition to a market economy, was the one entitled "A Healthy Romania", a study conducted between 1992 and 1993, being financed by the World Bank. Among the report's recommendations, I mention: the creation of an independent, decentralised and self-administered national public health insurance fund, the creation of alternative private health insurance funds, the decentralisation of health services, the emphasis on the importance of primary health services, the autonomy of hospitals in resource use, as well as the creation and implementation of an accreditation system for health care providers, both for institutions and for healthcare professionals.

The first years of the post-December transition were marked from a socio-economic point of view by a deep crisis that led to a decline in the standard of living of the population and a to deterioration of the confidence in state institutions and public service sectors. During this period, the health condition of the population suffered, both as a result of economic precariousness and the deterioration of the public health system. Between 1990 and 1995, life expectancy in Romania decreased from 69.7 years to 69.5 years while the mortality rate increased (Vladescu et al., 2008:8). Romanian state institutions and the political class have failed to provide the population with the basis for a better life, long awaited immediately after the December 1989 revolution. "Democratically elected politicians have not been able to create public policies to protect minorities, vulnerable groups and restore confidence in state institutions" (Manea, 2014). Consequently, all public services have come to be viewed in an unfavourable light by Romanians: inefficient, underperforming, poorly managed and infested by the phenomenon of corruption. The healthcare sector is no exception to these labels.

In 2001, the World Bank ${ }^{2}$ estimated in its report on corruption in Romania that in $47 \%$ of Romanian households there is a perception that almost all public health officials are corrupt. This percentage places the health sector at the same level as the Romanian Police and slightly below the Government and Parliament. In this period preceding Romania's integration into the European Union, one of the main reasons why patients or their relatives resort to informal payments is the access to doctors with a high reputation. There are thus a couple of disjointed perceptions about the competencies of doctors on the one hand and their seemingly questionable integrity on the other. However, it is

2 World Bank, „Diagnostic Surveys of Corruption in Romania”, 2001. Source: http://documents1.worldbank.org/curated/en/507421468776743543/pdf/289970R00Diagn1urveys0of0Corruptio n.pdf, last accessed on 20.04.2020 
important to keep in mind that poverty and low wages were seen as the main causes of corruption (idem). This, coupled with the voluntary nature of most informal payments, leads to the conclusion that patients often offer these payments as a reward for treatments received and in the form of compensation between the actual value of the medical act and the low salaries received by healthcare professionals. The statement is reinforced by the levels of satisfaction with the medical services received, included in the same report of the World Bank, which have values of over $70 \%$.

When do informal payments become central to the analysis of the critical points of the post-socialist health system? When are these stated as a social issue? The discourse on informality in the medical field is taking shape with the intensification of measures to liberalise the health system and due to the tightening of anti-corruption measures in the last two years prior to Romania's accession to the European Union. A turning point in the definition of political discourses on the specifics of informal payments is the legislative and presidential elections of 2004, which marked the shifting of the balance of power from PSD, the centre-left pole of Romanian politics, to the centre-right alliance "Justice and Truth", led by Traian Băsescu (President of Romania between 2004-2014). It is relevant to note that during the election campaign, the JT alliance took an extremely virulent stance against systemic corruption in Romania, for which it essentially accuses the leaders of the rival party, portrayed as successors of the communist system and main beneficiaries of informality, regardless of the field in which it manifests itself. Informal payments in the healthcare system are regulated in the legal framework for the first time in the article34 of Law number 46/2003, called "Patient Rights Law", which was approved by the Parliament during the PSD government. The text of the law clearly states that:

The healthcare or non-healthcare professionals of the health units do not have the right to put the patient under any form of pressure to determine the patient to reward him otherwise than the legal payment regulations within the respective unit. The patient may offer additional payments or donations to employees or the unit where he was cared for, in compliance with the law. ${ }^{3}$

This specification appears as "the patient's right to medical treatment and care" 4 . Basically, the law adopted during the government of Adrian Năstase does not criminalise the informal payments offered as a reward for the medical services offered on the patient's own initiative. Therefore, we can notice the

3 Law no. 46 of January 21, 2003, on patient rights, published in the Official Gazette Part I, no. 70 of January 29, 2003. Source: http://legislatie.just.ro/Public/DetaliiDocument/41483, last accessed on 04.03 .2021

4 idem 
relative tolerance from the legal point of view of the informal exchanges during the socialist government of PSD, a tolerance that disappeared, at least at a declarative level, after four years of neoliberal government. Thus, informal payments in the health sector are directly targeted as acts of "petty corruption" facilitated by "poor legislation" in the "National Strategy for Preventing and Combating Corruption in Vulnerable Sectors and Local Government (20082012)". The elaboration of this strategy took into account the conclusions of some institutional evaluations carried out in Romania, but also external sources such as the "Monitoring Report of the European Commission" (September 2006) $)^{5}$, "Report of the European Commission on the evolution of accompanying measures in Romania after accession" (Published in June 2007)6, Transparency International reports 7 , as well as "GRECO - Council of Europe Reports." Informal payment is identified in these documents as a specific problem of the health system, establishing a clear delimitation in relation to the rhetoric of 19902000. With Romania's accession to the European Union, due to a centre-right government, the transfer of the label of "corruption" becomes visible, at a discursive level and legislative, to the informal material practices in the public sectors as well as the compartmentalisation and isolation of the informal practices on fields of activity, in conjunction with their identification as specific problems of the fields in which they are found.

In 2005, CURS, a private company that conducts social research and market research, published the results of a survey conducted for the Ministry of Public Health, which found that the total informal payments made in the Romanian health system in 2004 could be estimated at over 300 million, most of which taking place in public hospitals. The results of this survey are mentioned in a 2008 report of the Presidential Commission for the analysis and elaboration of public health policies in Romania, entitled "Citizen's Needs". Written by a team of health experts, the report directly mentions informal payments which "limit and hinder access to various hospital services, a practice which in many cases acts as a method of de facto rationalisation of the services provided". (idem) Starting with 2007, with Romania's accession to the European Union, there is an

5 Commission of the European Communities, "Report on the state of preparation of Romania and Bulgaria for EU membership", 2006. Source: https://insse.ro/cms/files/cooperare/raport_septembrie_ro.pdf, last accessed on07.04.2021

6 Commission of the European Communities, "REPORT FROM THE COMMISSION TO THE EUROPEANPARLIAMENT AND THE COUNCIL on the evolution of accompanying measures in Romania after accession", 2007. Source: https://eur-lex.europa.eu/legal-content/RO/TXT/PDF/ ?uri=CELEX:52007DC0378\&from=RO, last accessed on 02.04.2021

7 Presidential Commission for the analysis and elaboration of public health policies in Romania, "A healthsystem focused on the needs of the citizen", 2008. Source: http://www.old.presidency.ro/static/rapoarte/Raport_CPAEPDSPR.pdf, last accessed on 08.09.2019 
exodus of Romanian doctors to the western states, the main incriminating reasons being the structural and financial problems of the Romanian health system. The reasons for these mass departures are many, the most frequently mentioned being the lack of respect from the state for the medical profession in Romania (exams, requirements, working conditions offered), low salaries but also lack of opportunities to progress in the country (public hospitals are outdated and run on a clientele system, hospital infrastructure private sector is still underdeveloped). More than a third of Romanian doctors with studies in the country choose to emigrate to practice abroad, according to a 2020 report by the Organisation for Economic Cooperation and Development (OECD) ${ }^{8}$ (please see Figure 1).

\section{Percentage of emigrant doctors, related to two coordinates: place of birth and educationin the local system.}

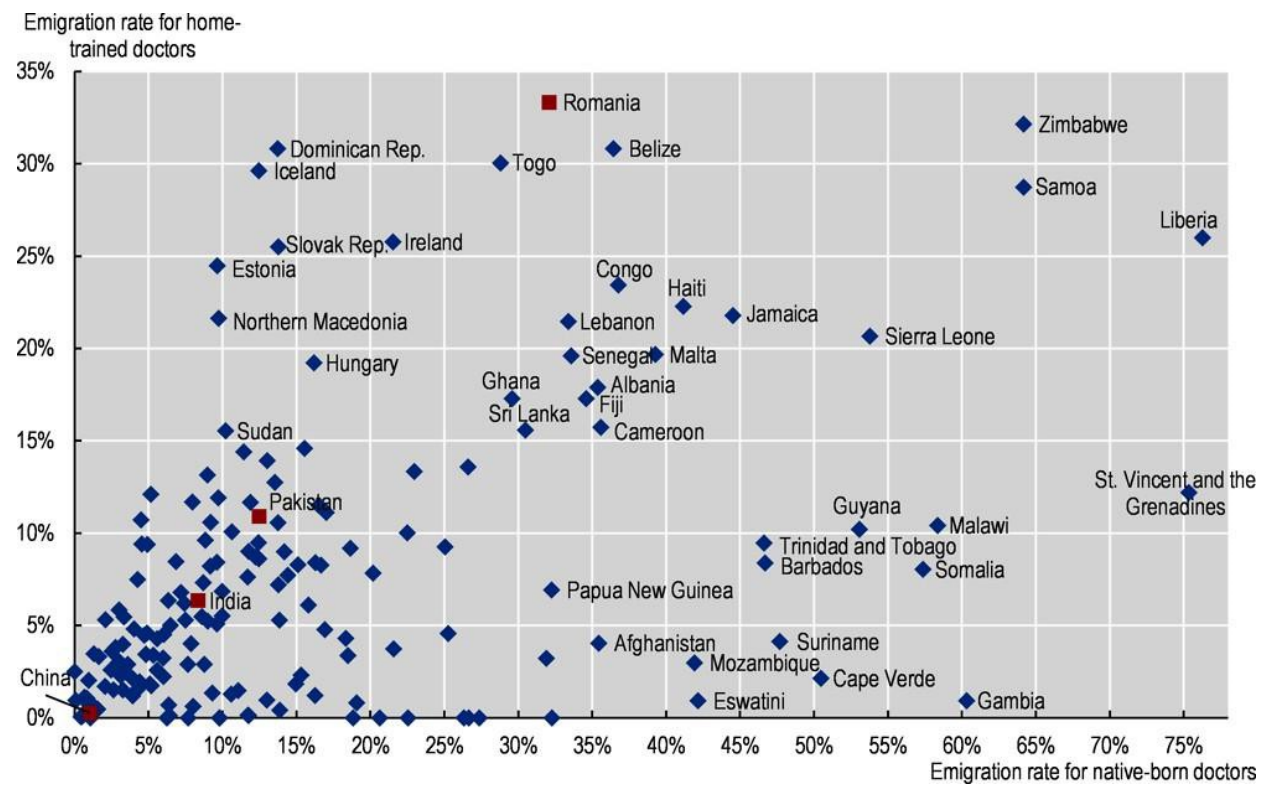

Source: Taken from the article "Contribution of migrant doctors and nurses to tackling COVID-19 crisis in OECD countries"9

8 OECD „Contribution of migrant doctors and nurses to tackling COVID-19 crisis in OECD countries”] Source: https://www.oecd.org/coronavirus/policy-responses/contribution-of-migrant-doctors-and-nurses-to-tackling-covid-19-crisis-in-oecd-countries-2f7bace2/\#figure-d1e1894, last accessed on 20.04.2021

9 idem 
This statistic places Romania on the first place in the world in an undesirable top of the percentage of doctors educated in the country of origin who choose to practice in other states. Although the press has raised numerous alarm signals and constantly lamented the way in which a health system is run, from which so many doctors decide to leave, some prominent voices in the political arena have taken neutral or even pro-phenomenon positions, thus hitting the reputation of Romanian healthcare professionals. For example, in 2010, the then president, Traian Băsescu, stated that doctors' departures should not be mourned because the state cannot integrate them into the public system and the large hospitals do not lack staff: "I agree that doctors go abroad for better salaries. The best thing was to liberalise the labor market. Let's not make a fuss about leaving. The Romanian state cannot pay its doctors and teachers as they deserve, that is the reality"10. The doctors who remain in the country, and especially those who return from abroad, are seen by some media outlets as heroes, who sacrifice their material well- being to fight for change in a poor system. The HotNews.ro news site published in 2013 a series of articles called "Doctor by profession in Romania"11, created at the initiative and with the support of the Council of Foreign Investors. The series is described on the site as "a series of HotNews.ro articles that describe the lives of several doctors who, despite the conditions, remain to work in Romania, no matter how incredible their motives may seem." I note from the formulation of this characterisation, the position of the publication towards the Romanian healthcare system and its doctors: a framework in which the exercise of the medical profession is extremely difficult, but in which certain extraordinary professionals choose to remain for altruistic reasons. At the same time, there is a continuous degradation of the image of active healthcare professionals in public health institutions, who are incriminated as the main responsible for perpetuating the phenomenon of informal payments ${ }^{12}$. In order to exercise increased control over the conduct of the medical act, the Ministry of Health has set up an "Ethical Council" (ibidem) in each public hospital - a control body on how the treatments are carried out in state health units. The attributions of the Ethics Council include the control and registration of informal payments made by patients within the health unit

10 Valentin Dimitriu, "Basescu: Let's not make a drama that doctors are leaving the country", August 4, 2010. Source: https://ziare.com/basescu/presedinte/basescu-sa-nu-facem-o-dramaca-pleaca-medicii-din-tara-1033470, last accessed on: 20.12 .2020

11 Hotnews.ro, "Doctor by profession in Romania". Source: https://www.hotnews.ro/de_profesie_medic_in_romania, last accessed on: 08.03.2021

12 Ministry of Health, "Order approving the composition and responsibilities of the Ethical Council operating inhospitals." Source: http://old.ms.ro/documente/Ordin\%20Consiliu\%20etic_ 1018_2022.pdf, last accessed on: 19.09.2016 
and the submission of notifications regarding these payments to the state authorities. Thus, indirectly, informal payments, requested or accepted without being reported, are regulated as violations of deontological norms in medical practice. However, the text of the same order specifies that "so far $(2010,0 . n$.) no solution has been found to limit/stop this phenomenon".

In the fall of 2009, the Ministry of Health proposes the introduction of health vouchers, starting with January 1,2010 , which are a form of additional payment for services in the public health system for treatments that do not fall into the category of emergencies. This form of co-payment was presented by the Minister of Health, from the Social Democratic Party (PSD) Ion Bazac, as a measure that would put an end to informal payments within a few months since the introduction: "It is a way of solving it, but it will not happen overnight. According to the polls, the hospital envelope is today the fifth cause of dissatisfaction of the population in Romania"13. The beneficiary of the amounts of money obtained from health vouchers is the hospital, and implicitly the state, as the administrator of the public health system, which is thus interposed as a front in the relationship between doctor and patient: "My thought is that people pay the tickets, not directly to the doctor but, let's say, at the cashier, they will be less tempted to come and give him the envelope too." (Ion Bazac, idem). Despite the political discourse, the public and the media perceived this system as an additional charge applied to a population largely unable to afford the standard costs of medical treatment other than emergencies. In reality, the introduction of co-payments for medical treatments in the public health system is a measure conditioned by the International Monetary Fund, meant to bring new funds to the Romanian state budget, the link between this system and informal payments being circumstantial at most. As the enactment of the copayment system would have obviously been an unpopular measure, especially due to the economic crisis at the end of 2009-2010, the neoliberal government has discursively created a bridge between this system and the interests of the population through the prognosis of elimination of informal payments. Minister Bazac is replaced at the end of 2009 by Cseke Attila, amid the political renegotiation of the composition of the Executive due to the withdrawal of PSD from governing with the Liberal Democratic Party (PDL) and the co-optation of the Hungarian Democratic Union (UDMR) in the majority alliance. Motivated by

\footnotetext{
13 Adevărul.ro, "The medical ticket leaves the informal payment in the hospital", September 23, 2009. Source: https://adevarul.ro/news/eveniment/tichetul-medical-lasa-spaga-spital-1_50acc 1ba7c42d5a6638982d8/index.html, last accessed on 20.05.2021
} 
IMF pressure, the co-payment is also supported by the new minister ${ }^{14}$, PDL Prime Minister Emil Boc, insisting that the benefits of this measure be presented to the public. The political discourse no longer makes direct reference to the elimination of informal payments through co-payment, stating only that "the new system will improve the relationship between patient and doctor in terms of the quality of the medical act" (Emil Boc, idem). Two years behind the originally proposed timetable, the co-payment law was published in the Official Gazette ${ }^{15}$, but the impact of this measure on informal payments proved to be minimal. On the contrary, instead of facilitating communication between doctor and patient, as the public discourse of politicians argued, copayment has become a mere additional expense for patients, representing a detrimental factor the for access to medical treatment of an already impoverished population. A World Bank study, published in September $2010^{16}$ and widely taken over by the Romanian press at the time, showed that informal payments in the healthcare system continued to amount to more than 300 million euros a year. Among the patients having admitted to using this practice, $89 \%$ said they offer informal payments to healthcare professionals "for fear that the doctor will not look at them", while the remaining $11 \%$ said they gave gifts to doctors as a reward for a very good quality treatment. However, the overwhelming majority of patients (unpublished percentage, o.n.) admitted that doctors did not condition the treatment on receiving goods or money, the main factor that led them to pay was the fear of the hypothetical consequences of not performing this act.

In the years 2009-2010, the legislative initiative of the Ministry of Health to introduce co-payment in the healthcare system, presented by the Government as a measure that would gradually lead to the elimination from the system of the causes underlying informal payments appears again: "It is a mentality that is not easy to remove, but with a good information campaign, informal payments will probably be gradually reduced. But as there is no such informal payment system in a private system, if we introduce co-payment and the patient is satisfied with the medical services, he will probably not use this

\footnotetext{
14 Mediafax.ro, "Cseke Attila: We will prepare the normative act on co-payment as it is a document undertaken with the IMF", February 10, 2010. Source:http://www.mediafax.ro/social/cseke-attila-vom-pregati-actul-normativ-privind-coplata-intrucat-este-un-documentasumat-cu-fmi-5493038, last accessed on: 18.09.2016

15 Official Gazette, Part I, no. 851 of November 30, 2011, last accessed on: 29.08.2016;

16 PRO TV news, "World Bank study: 300 million euros, informal payment for doctors in one year", October 30, 2012. Source: http://stirileprotv.ro/stiri/social/studiu-banca-mondiala300-de-milioane-de-euro-spaga-la-medici- intr-un-an.html, last accessed on: 20.09.2016
} 
type of services ${ }^{17}$, said the then Minister of Health, Ion Bazac, about the impact of the co-payment system on so-called "informal payments" in hospitals. However, the impact of the co-payment system proved to be insignificant, even contrary to the initial intentions of the Government according to certain voices: (The patient, o.n.) will not only pay five to ten lei, because he is ashamed. The doctor will issue his receipt for ten lei, he will pay one hundred. Unlike France, Romania is not ready to adopt such a measure, because here the mentality is to give", said in 2012 Vasile Barbu, then president of the "Romanian Patients Association".

In 2011, the presidential administration strongly supported the full privatisation of health services, presented as the best way for doctors to reach competitive salaries that reflect the volume and quality of the work done, without a huge budget effort from the state. In fact, throughout 2011, the Cotroceni Palace strongly promoted, both in the political environment and in the media, the gradual transition to a private health system, also reaching the subject of informal payments. In August 2011, the "Presidential Commission on Health" submitted to the Government a report meant to be the basis of the new "Health Law". The text of the report contains four points whose implementation would have been meant to eliminate this phenomenon of informal payments ${ }^{18}$, along with the revision of the salary scale for healthcare professionals: imposing clear sanctions against those who accept informal payments; introduction of mechanisms for formalising some of the unofficial payments (with measures to protect the accessibility of the economically disadvantaged groups); stimulating the development of a private health sector, both for private health insurance and for the provision of comprehensive health services, modifying service payment systems to encourage efficient services and professional performance.

With the installation of the technocratic government led by Dacian Cioloş, towards the end of 2015, the political discourse on the situation of informal payments was reoriented again towards the neoliberal specifics, identifying them with acts of corruption that are part of the pathology of a gangrenous health system. Although he was repeatedly accused by a politically affiliated media

17 Gândul.ro, "The Minister of Health wants to give money legally to the doctor to get rid of the informal payment", April 26, 2012. Source: http://www.gandul.info/stiri/ministrul-sanatatiivrea-sa-dam-bani-legal-doctorului-ca-sa-scapam-de-spaga-video-3950006, last accessed on 31.03.2017

18 Raluca Pantazi, "What are the solutions for Health in the report of the Presidential Commission, which Băsescu said he was sending to the Government as a starting point for the new Health Law", August 4, 2011. Source:http://www.hotnews.ro/stiri-esential-9672621-care-sunt-solutiile-pentru-sanatate-din-raportul-comisiei-prezidentiale-despre-care-basescu-spus-trimiteguvern-punct-plecare-pentru-noua-lege-sanatatii.htm, last accessed on 02.04.2017 
party of trying to privatise hospitals again, Cioloş denied this, suggesting instead that he wanted a revitalisation of state hospital infrastructure through a partnership with the private environment. The public-private partnership would have acted mainly in order to modernise Romanian hospitals through infrastructure works and providing them with modern medical equipment. At the same time, private companies would support the state in starting projects for new health facilities, so that the coverage of the medical network among the population will increase. Obviously, all these measures would have the effect of increasing transparency in the conduct of the medical act, facilitating access to logistical resources inside hospitals, thus cutting the chain of dual medical practice.

It is important to draw a parallel between the period of democraticliberal government of the years 2004-2012 and its previous years, on the coordinates of the measures and political positions of the main actors in relation to the phenomenon of informal payments in the health system. A common feature of both chronological intervals is the minimal involvement of the state in the recovery of non-functional elements of the health system. Doctors' salaries have remained and patients' rights were regulated late by interpretable and ambiguous legislation. Under these circumstances, one can say that not only has the state tolerated or ignored informal payments in the health system in the first 25 years since the replacement of the communist regime, but it has even stimulated them.

During the 2014-2015 period, the media deals extensively with the subject of the membership of doctors employed in state health units in the category of civil servants. The subject is of particular interest for the purpose of this paper because, in 2014, Article 175 of the Criminal Code underwent amendments according to which doctors employed in public institutions are included in the broader category of civil servants, therefore, according to the same normative act, Articles 289-292, they are liable to be charged with bribery in the event of the acceptance of informal payments:

By this decision it was established that the doctor carries out his activity in the performance of a service of public interest and that the doctor employed with a contract of employment in a hospital unit of the public health system has the qualityof a civil servant, falling into the category of those who' exercise a public function of any nature referred to in art. 175, para. 1., letter B, second thesis, Criminal Code"(Cristi Dănileț, member of the Superior Council of Magistracy ${ }^{19}$ ).

19 Cristi Dănileț, "The doctor is liable in the same way as a civil servant if he commits corruption offenses", August 17, 2015. Source: http://www.contributors.ro/administratie/medicul-raspunde-la-fel-ca-un-functionar-public-daca-comite-infractiuni-de-coruptie/, last accessed on: 25.09.2016 
Thus, the special cases stipulated in Law 46/2003 are eliminated from the legal framework - the unconditional material benefits, offered as a reward for the medical services on the patient's own initiative. The quality of civil servant of the doctor employed in the public health system was definitively confirmed by a decision of the High Court of Cassation and Justice on June 4, $2015^{20}$, causing a wave of dissatisfaction from the College of Physicians in Romania. In order to understand how the legal quality of the medical profession has reached the attention of the media and the public, we must refer to the Emergency Ordinance number 2/2014, amending Law no. 95/2006, a measure of the PSD government led by Victor Ponta, by which the medical profession is granted a liberal status and, implicitly, is exempted from the provisions of the Criminal Code on corruption among civil servants.

Initially, the normative act was not promulgated by President Traian Băsescu, who expressed his objections to its provisions. In his request for reexamination sent to Parliament, the President stated that the removal of doctors from the category of civil servants diminished their criminal liability for "all offences in which the active subject is a civil servant within the meaning of criminal law"21. However, the Senate Health Committee rejected the president's arguments, justifying its decision by the need to align with the provisions of the other member states of the European Union, where the medical profession is "liberal par excellence". At the same time, the parliamentarians supported the need to liberalise the quality of doctor based on a series of "sociological studies" not indicated, according to which doctors leave Romania en masse due to the fact that they do not enjoy professional independence and are treated like civil servants. Practically, the Parliament equates conferring the state of the liberal profession on medical practice with an active measure taken to stop the migration of medical staff to other states. The College of Physicians in Romania welcomed the Government's measure in a statement on its website ${ }^{22}$, considering that it is a legislative act that consolidates the independence of the medical profession, while defending the interests of the patient:

20 Avocatnet.ro, „HCCJ Decision no. 19/2015 - doctors who are civil servants cannot receive additional payments or donations", August 7, 2015. Source: http://www.avocatnet.ro/content/articles/id_41160/Decizia-HCCJ-nr-19-2015-medicii-care-au-calitatea-de-functionarpublic-nu-pot-primi-plati-suplimentare-sau-donatii.html, last accessed on: 21.09.2016

21 Valentina Postelnicu, "President Băsescu promulgated the law removing doctors from the category of civilservants", October 8, 2014. Source: http://www.mediafax.ro/social/presedintele-basescu-a-promulgat-legea-care-scoate-medicii-din-categoria-functionarilor-publici13372495, last accessed on: 18.09.2016

22 Elvira Gheorghiță, "CPR against the HCCJ decision: Doctors are not civil servants, the legislation allows donations", August 14, 2015. Source: https://www.mediafax.ro/social/cmr-fatade-decizia-HCCJ-medicii-nu-sunt-functionari-publici-legislatia-permite-donatii-14675821 
Given the nature of the profession, the doctor is not a civil servant and cannot be assimilated to such. Prosecutors will have nothing to look for in the doctor's office, because I had a case of a doctor arrested for a $3 \mathrm{~kg}$ jar of honey, considering that neither the doctor nor the patient complained. Now the law willhave to be enacted. (Vasile Astărăstoae, president of $\mathrm{CPR}^{23}$ ).

Interpreted in the form proposed by the Ponta Government, the law led to an acquittal in the case of military doctor Iancu Mocanu, who was exonerated of criminal liability by the Bucharest Military Tribunal in March 2014 for taking bribes and receiving undue benefits. The doctor was caught red-handed on September 23, 2013, when he took a bribe of 2,000 euros to operate on a patient. The doctor told investigators that the amount found in his pocket, in the left side of the blouse was received "as consideration from a patient's family member." The situation came to the attention of the Supreme Court, when it was referred to a lower court that found that there is non-unitary jurisprudence in the legislation, and the interpretation of the legal texts is unclear. On December 3, 2014, the Court ruled: doctors who are employed in state health units are civil servants, thus not being deprived of criminal liability in the case of bribery offences stipulated in the Criminal Code. As I mentioned before, the appeals against this decision were rejected without appeal by the High Court of Cassation and Justice in the summer of 2015, a decision virulently criticised by the new president of the College of Physicians, Gheorghe Borcean: "Since the legal official courts were unclear on this case, it is obvious that the law is not clear, it is not precise, it is not a working tool as it should be" (Gheorghe Borcean) ${ }^{24}$. Referring to the informal payments in the health system, he added that patients' practices of rewarding doctors for the treatments received have become a tradition in Romania, precisely because of the insufficient salary of hospital staff:

At the same time we all know that it is a custom, it is a tradition this situation in Romania where the patient rewards the doctor's work for various reasons, because he wants it, because he knows that doctors' salaries are low. It is also well known that the doctor's financial situation has been embarrassing for years. I can't say how frustrating it is for a doctor to feel dependent on a consideration,a gift, a donation that the patient makes (...) All doctors will say that their income is dependent on this form of funding. (...) It is frustrating that these things are happening due to some legislative ambiguities, which do not honour us, the 40,000 doctors who work in Romania, nor our patients (...) (Gheorghe Borcean)

\footnotetext{
23 colegiul-medicilor-vasile-astarastoae-sa-serbam-victoria-procurorii-nu-vor-mai-avea-ce-sacaute-in-cabinetul-medical.html, last accessed on: 21.09.2016

24 idem
} 
From the statement of the President of the CPR, we can extract an image of informal payments, as they are seen by doctors - not as acts of corruption, but as donations and gifts that patients offer out of gratitude, with three main goals: strengthening the empathy of healthcare professionals for the patient, implicitly taming the medical gaze, facilitating the communication between the patient, his family members and the healthcare professionals and rewarding to an adequate value the services of the healthcare professionals, a remedy of the underpaid medical team. In August 2015, Prime Minister Victor Ponta and the Minister of Health, Nicolae Bănicioiu, announced that The government has begun work on a bill to regulate the legal conditions under which doctors can receive informal payments without being accused of corruption. Regarded by the media and the public as "legalising informal payments to doctors", the legislative idea that the prime minister demanded from the Ministry of Justice was to define three conditions for an informal payment to be considered legal: not to be conditioned by the doctor, to occur after the end of the patient's treatment and to be declared so that it can be taxed. Coming with an announcement of a $25 \%$ increase in salaries in the healthcare system from October 1, 2015, Prime Minister Ponta's statement directly ignored the decision of the Supreme Court, High Court of Cassation and Justice, regarding the doctors being civil servants.

The Government's approach must be understood in the context of the pressures exerted by doctors in 2015 to increase salaries in the system and improve working conditions, thousands of healthcare professionals forming a group called the "Alliance of Physicians" and threatening a large-scale strike ${ }^{25}$. The purpose of this legislative initiative was triple: on the one hand, the Executive wanted to alleviate the dissatisfaction of doctors, providing them with a legal instrument through which to receive informal payments, thus postponing the adoption of real measures to solve problems in the healthcare system. On the other hand, by introducing informal payments into the tax system, the state was to take a share of the total amount of previously unofficial and implicitly nontaxable transactions between doctors and patients - an amount not to be ignored, taking into account the estimates of studies conducted which constantly placed the total value of the annual informal payments made in Romania between 300 and 400 million euros ${ }^{26}$. Ultimately, the Government has sought to attract the sympathy of doctors and the public for the decriminalisation of this widespread practice,

25 Formaremedicala.ro, “Doctors do not give up. The doctors' alliance declined the Government's invitation to participate in the talks", August 18, 2015. Source: https://www.formaremedicala.ro/medicii-nu-cedeaza-alianta- medicilor-a-declinat-invitatia-guvernului-de-a-participala-discutii/, last accessed on: 24.09.2016

26 Digi24.ro, "What does the envelope for doctors contain and why do patients not give it up", July 9, 2016 http://www.digi24.ro/stiri/actualitate/social/ce-contine-plicul-pentru-medici-si-dece-nu-renunta-pacientii-la-el-540153, last accessed on: 20.09.2016 
by removing doctors and patients involved from the provisions of the Criminal Code on the offences of giving and taking bribes, based on the adverse reactions of the College of Physicians regarding the decision previously taken in the same year by the supreme court - to place informal payments in the health system under the legal provisions on corruption. However, the result was completely opposite to the expectations of Prime Minister Ponta. Doctors have declared themselves offended by the idea of a law for legalising and taxing informal payments ${ }^{27}$, and the media broke out against the Government, accusing the idea of "legalising the informal payments" 28 . Considering such pressure, the bill disappeared from the debate, and a possible piece of legislation was passed instead to allow patients to pay taxable amounts of money in order to choose the doctor to treat them, this fee being a payment for the reputation and experience of the doctor. This measure was not welcomed by the healthcare professionals either, the representatives of the Alliance of Physicians claiming that: "Lawmaking of the fee introduces inadmissible discrimination between hospitalised patients, state or private and predisposes to the violation of the rights of the patient, treated as a private in the public system, or the law must have a preventive role against possible abuses" 29 .

In the following months, the attention of the public, the press and politicians was captured by cases of great corruption in the administrative and health systems, with the fire in the Bucharest club "Colectiv", which revealed major shortcomings in the way the Romanian health system works. We must mention that, following the street protests against corruption and the political class, PSD Prime Minister Victor Ponta resigned, replacing his government with the most apolitical cabinet since the Revolution, headed by former European Commissioner Dacian Ciolos. The new prime minister equally condemns all acts of corruption in the system, urging citizens to distance themselves from the old habits of informal payments:

27 Denisa Miron, “Doctors' reaction to government announcement: We don't want legalization of informal payments", August 18, 2015. Source: http://www.stiripesurse.ro/reactia-medicilordupa-anuntul-guvernului-nu-vrem-legalizarea-spagii_964577.html, last accessed on: 25.09.2016.

28 G.S., The Alliance of Physicians is "definitely against the legalization of informal payments" for doctors: This practiceis degrading for both the patient and the doctor", August 19, 2015. Source: http://www.hotnews.ro/stiri-esential-20366909-alianta-medicilor-este-categoric-impotriva-legalizarii-spagii-pentru-doctori-aceasta-practica-este-degradanta-atat-pentru-pacientcat-pentru-medic.htm, last accessed on: 17.09.2016.

${ }_{29}$ PRO TV news, "What happened with the doctors' informal payments legalization project. Doctor: "What to ask fromthem? I can't say that the sick are rich", August 29, 2015. Source: http://stirileprotv.ro/stiri/sanatate/proiectul-pentru-legalizarea-spagii-pentru-medici-a-disparutla-fel-de-repede-cum-a-aparut-cum-e-stabilit-onorariul-actual.html, last accessed on: 24.09.2016. 
Here I am thinking of the «consideration» we pay at the counter to the money slipped into the doctor's pocket - with or without his will - here I am talking about our attitude, everyone's, to the corruption in the big infrastructure projects. Every act of corruption weakens the Romanian state and takes us away from a healthy society. $(. . .)^{30}$

In conclusion, we can appreciate that the semantics of the official neoliberal discourse on "bribery" do not possess any dose of sensitivity about the ambivalence that the social actor - healthcare professionals, patient or family member - feels about informal medical payments. The political agenda, strongly based on imagining medical services in line with the strategic interests of a free, transparent and regulated by supply and demand market, resorts to criminalising informality, arguing in front of the public that the system will be released of the reminiscent problems of the socialist period. I believe that in post-socialism we are not talking about maintaining informal payments amid insufficient liberalisation of the health care market, but about adaptive strategies that the social actor recomposes as they face growing inequalities in access to health care. As we have shown in the pages above, in Romania we have witnessed an unprocessed emulation of systems and measures imposed by Western neoliberal institutions and European Union partners in the field of health, while the rights of doctors and patients have remained captive in a grey area, uncertain about the laws and measures that should have regulated and strengthened them. The ambiguous status of these payments allows for the updating of reprehensible attitudes, when tacit acceptance and their definition as a self-evident reality, beneficial rather than faulty, in line with the way government decision-makers imagine plans to reform one of the sectors with the highest stake in terms of allocated resources and public interest: the state health system.

At the beginning of 2020, the world was on the verge of a global epidemic caused by the spread of the SARS-CoV 2 virus beyond China's borders. Healthcare systems in almost every country in the world were going to be under enormous pressure that generated dramatic periods even in the most developed countries. As outbreaks spread throughout Europe, there were huge questions in Romania about the ability of the inefficient state health system to cope with a potentially huge wave of cases similar to those in China or Italy. Late in preparation for this challenge, the healthcare sector has once again shown its

30 I.C., "Government launches new National Anticorruption Strategy", July 19, 2016. Source: http://www.hotnews.ro/stiriesential-21167877-live-text-guvenul-lanseaza-noua-strategienationala-anticoruptie-ciolos-atentia-care-acordam-ghiseu-baniistrecurati-buzunarul-medicului-coruptia-din-marele-proiecte-insfrastructura-fiecare-act-slabes.htm, last accessed on: 24.09.2016. 
shortcomings: poor management, excessive politicisation, staffing crisis, inadequate provision of hospital facilities with modern technologies and equipment.

The COVID-19 pandemic in Romania started relatively simultaneously with the media coverage of a famous corruption case involving Sorina Pintea, former Minister of Health in the last Social Democratic government. On February 29, just 3 days after the confirmation of the first case of COVID-19 in the country, Pintea was arrested for bribery, being accused of receiving a sum of over 35,000 euros, representing $7 \%$ of the value of a modernisation contract, in the form of a public procurement of the hospital in which she operated as a manager ${ }^{31}$. At the beginning of the same month, a survey conducted by IMAS at the request of EuropaFM carried out an x-ray of the level of confidence of the population in the various components and institutions of the healthcare system in early 2020, amid the escalation of the health crisis. (Please refer to Figure 2). Thus, we can observe that at the dawn of the COVID-19 pandemic, over $60 \%$ of Romanians did not trust state hospitals and approximately 57\% did not trust the Ministry of Health. On the other hand, doctors in Romania as well as private hospitals enjoyed the trust of the majority of the population.

Figure 2.

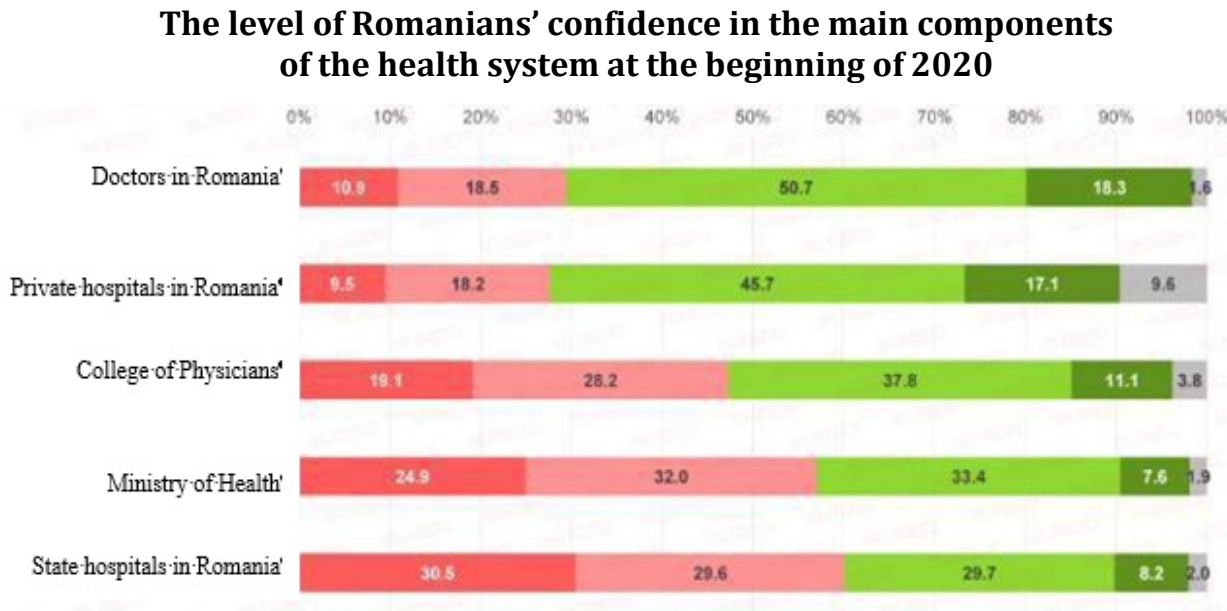

Source: Europa FM Barometer: Do Romanians Trust State Hospitals? Do they agree with the optionalincrease of the retirement age?, February 3, 2020

31 Digi 24.ro, "Sorina Pintea, sent to court for taking bribes". April 30, 2020. Source: https://www.digi24.ro/stiri/actualitate/justitie/sorina-pintea-trimisa-in-judecata-pentruluare-de-mita-1299828, last accessed on 22.04.2021 
The pandemic event that started in Romania at the beginning of 2020 and in which we are still, was a difficult test for the national healthcare system, registering major fluctuations in relation to the public perception of the healthcare professionals. While in the West the healthcare professionals enjoyed almost unanimous support and appreciation from them the media and the population, doctors, nurses and orderlies being portrayed and honoured as true heroes in the fight to limit the impact of the pandemic, in the spring of 2020 Romania was marked by public scandals generated by the transformation of hospitals into real outbreaks of the new coronavirus poor management at the medical unit level but also against the background of the acute lack of protection and training equipment regarding their use. Eloquent in this sense is the episode that happened at the beginning of the pandemic at the Suceava County Hospital where, due to management and communication errors, a large part of the healthcare professionals became infected even before they could take over and treat the flow of patients, fact which amplified the epidemic balance in this region of the country. If the dominant media discourse in the coming months focused on portraying healthcare professionals in the form of pandemic heroes, frequently presenting reports and articles praising the efforts of doctors and nurses, especially in the Intensive Care Units, where the severe cases of COVID-19 were treated, the perception of the population remained fragmented: a significant part of Romanians, dissatisfied with the restrictions imposed and the actions taken by the authorities to limit the pandemic, continued to deny the existence of the danger posed by the virus, to question the authenticity of tragic images in hospitals and to accuse occult interests in publicising the danger posed by COVID-19.

This polarisation of the public has been intensely fuelled by differences in the level of discourse of the main political actors, the year 2020 being loaded with a huge political stake: local and parliamentary elections. Thus, the opposition represented by the Social Democratic Party constantly criticised the governmental measures while the new parliamentary party Alliance for the Union of Romanians (AUR), with nationalist orientation, constantly organised protests with the stated purpose of provoking the lifting of restrictions such as compulsory wearing of protection masks, restricted movement, closure of the HoReCa sector or compulsory hospitalisation of patients diagnosed with SARS$\mathrm{CoV}$ virus 2 . An important event in the chronology of the pandemic occurred in June 2020, when Renate Weber, Romanian Ombudsman, a supporter of the previous governing alliance (PSD-ALDE) imposed monitoring of hospitals for 
"prevention of torture or treatment specific to places of detention"32, justifying this measure by the fact that patients did not have the right to be discharged upon request, the hospital thus falling within the definition of a detention unit in which patients are deprived of their liberty.

The action of the Romanian Ombudsman thus legitimised the opinions of that part of the population that sympathised with the radical positions of AUR and some extreme voices within PSD, namely that the restrictions violate civil liberties and human rights, hospitals are places where patients are illegally hospitalised and subjected to torment by healthcare professionals. The protests against the so-called "medical dictatorship" culminated in the spring of 2021, amid the deepening epidemiological crisis and the overburdening of the health care system. While the intensive care units were overcrowded, in a crisis of beds and staff, a vocal minority manifested itself, sometimes even violently, near hospitals with slogans such as "Assassins!" addressed directly to the healthcare professionals. ${ }^{33}$ The manager of the "Matei Balș" hospital in Bucharest stated in March 2021 that:

From the point of view of the attitude towards the medical and auxiliary staff, we are amazed, watching how we turned torturers, criminals, assassins from heroes. Let's see what happens next. At some point it becomes painful to spend the day in the hospital, the nights, and then to be labelled as criminal, a psychopath, a terrorist. All we do is heal or improve (... $)^{34}$

With the improvement of the epidemiological situation in Romania, accompanied by the gradual lifting of restrictions, the demonstrations against doctors have ceased, but I note that even today no social and media consensus has been reached on the role of healthcare professionals during the pandemic. "Frontline heroes" for most are in the same time "killers" and "torturers" for others. At the same time, the COVID-19 pandemic caused two incidents that brought back to the public's memories of the tragedy that happened in 2015 in the "Colectiv" club: fires with loss of life occurred in Intensive Care Units. The

32 Alina Mihai, "Renate Weber explains why hospitals are being monitored by the Romanian Ombudsman for 'prevention of torture or treatment specific to places of detention' ", June 11, 2020: https://www.mediafax.ro/social/renate-weberexplica-de-ce-spitalele-sunt-monitorizate-de-avocatul-poporului-pentru-prevenirea-torturii-ori-tratamente-specificelocurilor-de-detentie19275263, last accessed on 28.05.202

33 Dan Tăpălagă, "Who are these rioters?", March 31, 2021. Source https://www.g4media.ro/cinesunt-acesti-revoltati.html, last accessed on 29.05.2021.

34 Răzvan Căucean, "Doctors' reaction to protests in front of hospitals: "From heroes we became torturers and assassins", March 31, 2021. Source: https://dej24.ro/reactia-medicilor-la-protesteledin-fata-spitalelor-am-ajuns-din-eroi-tortionari-si-asasini/, last accessed on 29.05.2021. 
first of these cases, which took place on November 15, 2020 at the Piatra Neamt County Emergency Hospital, had in the foreground the doctor on duty, Cătălin Denciu, who risked his life to get as many patients as possible out of a room in flames. The doctor, seriously injured, with burns on $80 \%$ of his body surface, was immediately considered a hero by both the Romanian and foreign press.

Painfully and outrageously, Romania was again, 5 years after the "Collective" moment, unable to treat the "great burned", the hero-doctor being immediately transferred to Belgium in order to benefit from the best care and higher chances of recovery. After years in which policymakers competed in promises to modernise state hospitals in order to cope with all kinds of emergencies and treatments, Nelu Tataru, the then Minister of Health, made an extremely controversial statement at the time by which denounced the collective guilt of all for what happened in Piatra Neamț in November 202035:

For 30 years, and for the local authorities and non-involvement, I think we are all guilty in this country, not only the healthcare system and not only the local authorities, because we have agreed for 30 years to live in such a medical situation.

Nelu Tătaru's statement is a call to make the population responsible for fighting the deficiencies in the health system: the state cannot fully solve the problems of the system and it is necessary that citizens no longer accept this "status quo" and change their mentalities regarding the medical situation in Romania.

From this unfortunate event, however, emerged the same opposition between the exemplary medical professionalism led to self-cancellation shown by Dr. Cătălin Denciu, and the inefficient, corrupt and outdated system that is maintained in a relative state of operation only at the cost of these sacrifices which are chosen by professionals who decide to stay in Romania to help their communities. Against the background of the measures of distancing and isolation during the pandemic, coupled with the concentration of resources of the health system to treat cases of COVID-19, I estimate that in this completely atypical period the phenomenon of informal payments has decreased in size. It will be important to note, however, how the system will readjust to "normality" as the coronavirus spread decreases. Will informal payments return to prepandemic levels? Will the Romanian health system enter a long-awaited

35 G4Media.ro, "Nelu Tătaru, about the fire in Piatra Neamț: We are all guilty because we accepted 30 years to live in such a medical situation", November 15, 2020. Source: https://www.g4media.ro/nelu-tataru-suntem-toti-vinovati-ca-am-acceptat-30-de-ani-sa-traim-intr-o-astfel-desituatie-medicala.html, last accessed on 29.05.2021 
modernisation process marked by relevant reforms? And if so, how will this process affect the phenomenon of informal payments and the ways in which patients and healthcare professionals relate? All of these remain open questions to which I will look for answers in the future.

\section{Conclusions: The scapegoat theory and the small (BIG) corruption}

In the conclusion of this paper I consider it important to establish from the outset that there is a profound lack of understanding and consistency of the health and political authorities in Romania that have succeeded each other in the great decision-making positions on health in the three decades since the fall of communism, in how to approach the phenomenon of informal payments. First, informal exchange practices between patients and their family members, on the one hand, and medical staff on the other, are not a dark legacy of the declining communist regime, but an extension of the formal framework that remains necessary in the context in which the health sector is facing a worsening of chronic problems due to the concrete lack of action on the part of policy makers. Like any exchange, informal payments have benefits for both parties involved. The fact that these benefits, on the periphery of the legal framework, are necessary for the lubrication of the mechanisms of a cumbersome system, for which the functioning of the legislative levers has proved insufficient over the last thirty years, is reversed and transformed by the political discourse in the reason for which the long-awaited reforms are delayed. Thus, informal post-socialist relations become, from an ideological point of view, obstacles to achieving the objectives of restructuring the system and aligning with the standards of economic performance specific to developed countries in the West.

Aware of their roles as opinion leaders, the political class and the major media outlets have turned the informal economy into a public enemy of the first rank, regardless of its declarative significance for both health professionals and citizens who are aware that staying formal does not guarantee health needs. In terms of public sector funding, informal payments have become not only a main target of criticism, but also an excuse for underfunding and lack of reformist modernisation measures, while major acts of corruption, procurement, supply and large-scale public contracts continued relatively unnoticed until the tragic occasion of the fire in the "Colectiv" club in the fall of 2015. I noticed, however, that depending on the political colours of the parties or alliances that succeeded each other in the reins of power, the measures proposed to stop the informal economy varied according to party ideologies. If the increase in salaries for the 
medical staff categories was a common promise of each Government, potentially or in office, approaches to the legal framework varied. The PSD Social Democrats, with a theoretically leftist orientation, have sought ways to allow legal loopholes for informal payments except for those conditioned by the provision of medical services, or even proposed legislative initiatives to assimilate them into the "white" economy over time, while right-wing governments after 2004 have labeled them globally as "bribes," "informal payments for doctors," or "corruption." Informalityas-gift, i.e. the situation in which the medical act is not in any form conditioned, most often seeks to replace the "medical gaze" with a human gaze, appropriate, non-hierarchical and non-paternalistic, "forcing" the healthcare professional to a type reciprocity that takes the form of recognising the other's humanity by personalising the therapeutic or care relationship.

\section{CITED DOCUMENTS AND LEGISLATION}

World Bank, "Diagnostic Surveys of Corruption in Romania", 2001. Source: http://documents1.worldbank.org/curated/en/507421468776743543/pdf/ 289970R00Diagn1urveys0 of0Corruptio n.pdf, last accessed on: 20.04.2020.

Law no. 46 of January 21, 2003, on patient rights, published in the Official Gazette Part I, no. 70 of January 29, 2003. Source: http://legislatie.just.ro/Public/Detalii Document/41483, last accessed on: 04.03.2021.

Commission of the European Communities, "Report on the state of preparation of Romania and Bulgaria for EU membership", 2006. Source: https://insse.ro/ cms/files/cooperare/raport_septembrie_ro.pdf, last accessed on: 07.04.2021.

Commission of the European Communities, "Report from The Commission to The European Parliament and The Council on the evolution of accompanying measures in Romania after accession", 2007. Source: https://eur-lex.europa.eu/ legal-content/RO/TXT/PDF/?uri=CELEX:52007DC0378\&from=RO, last accessed on: 02.04.2021.

Presidential Commission for the analysis and elaboration of public health policies in Romania, "A health system focused on the needs of the citizen", 2008. Source: http://www.old.presidency.ro/static/rapoarte/Raport_CPAEPDSPR.pdf, last accessed on: 08.09.2019.

OECD "Contribution of migrant doctors and nurses to tackling COVID-19 crisis in OECD countries"] Source: https://www.oecd.org/coronavirus/policy-responses/ contribution-of-migrant-doctors-and-nurses-to-tackling-covid-19-crisis-inoecd-countries-2f7bace2/\#figure-d1e1894, last accessed on: 20.04.2021.

Valentin Dimitriu, "Basescu: Let's not make a drama that doctors are leaving the country", August 4, 2010. Source: https://ziare.com/basescu/presedinte/ basescu-sa-nu-facem-o-drama-ca-pleaca-medicii-din-tara-1033470, last accessed on: 20.12.2020. 
Hotnews.ro, "Doctor by profession in Romania". Source: https://www.hotnews.ro/ de_profesie_medic_in_romania, last accessed on: 08.03.2021

Ministry of Health, "Order approving the composition and responsibilities of the Ethical Council operating in hospitals." Source: http://old.ms.ro/documente/ Ordin\%20Consiliu\%20etic_1018_2022.pdf, last accessed on: 19.09.2016.

Adevărul.ro, "The medical ticket leaves the informal payment in the hospital", September 23, 2009. Source:https://adevarul.ro/news/eveniment/tichetul-medical-lasaspaga-spital-1_50acc1ba7c42d5a6638982d8/index.html, last accessed on: 20.05.2021.

Mediafax.ro, "Cseke Attila: We will prepare the normative act on co-payment as it is a document undertaken with the IMF", February 10, 2010. Source: http://www.mediafax.ro/social/cseke-attila-vom-pregati-actul-normativ-privind-coplata-intrucat-este-un-document-asumat-cu-fmi-5493038, last accessed on: 18.09.2016.

Denisa Miron, “Doctors' reaction to government announcement: We don't want legalisation of informal payments", August 18, 2015. Source:

http://www.stiripesurse.ro/reactia-medicilor-dupa-anuntul-guvernului-nuvrem-legalizarea- spagii_964577.html, last accessed on: 25.09.2016.

G.S., The Alliance of Physicians is "definitely against the legalisation of informal payments" for doctors: This practice is degrading for both the patient and the doctor", August 19, 2015. Source: http://www.hotnews.ro/stiri-esential20366909-alianta-medicilor-este-categoric-impotriva-legalizarii-spagii-

pentru-doctori-aceasta-practica-este- degradanta- atat-pentru-pacient-catpentru-medic.htm, last accessed on: 17.09.2016.

PRO TV news, "What happened with the doctors' informal payments legalisation project. Doctor: "What to ask from them? I can't say that the sick are rich ", August 29, 2015. Source: http://stirileprotv.ro/stiri/sanatate/proiectul-pentrulegalizarea-spagii-pentru-medici-a-disparut-la-fel-de-repede-cum-a-aparutcum-e-stabilit-onorariul-actual.html, last accessed on: 24.09.2016.

I.C., "Government launches new National Anticorruption Strategy", July 19, 2016. Source: http://www.hotnews.ro/stiriesential-21167877-live-text-guvenul-lanseaza-noua-strategie-nationala-anticoruptie-ciolos-atentia-care-acordamghiseu-banii-strecurati-buzunarul-medicului-coruptia-din-marele-proiecteinsfrastructura-fiecare-act-slabes.htm, last accessed on: 24.09.2016.

PRO TV news, "World Bank study: 300 million euros, informal payment for doctors in one year", October 30, 2012. Source: http://stirileprotv.ro/stiri/social/studiubanca-mondiala-300-de-milioane-de-euro-spaga-la-medici-intr-un-an.html, last accessed on: 20.09.2016

Gândul.ro, "The Minister of Health wants to give money legally to the doctor to get rid of the informal payment", April 26, 2012. Source: http://www.gandul.info/ stiri/ministrul-sanatatii-vrea-sa-dam-bani-legal-doctorului-ca-sa-scapam-despaga-video-3950006, last accessed on: 31.03.2017. 
Raluca Pantazi, "What are the solutions for Health in the report of the Presidential Commission, which Băsescu said he was sending to the Government as a starting point for the new Health Law", August 4, 2011. Source:

http://www.hotnews.ro/stiri-esential-9672621-care-sunt-solutiile-pentru-sanatate-din-raportul-comisiei-prezidentiale-despre-care-basescu-spus-trimiteguvern-punct-plecare-pentru-noua-lege-sanatatii.htm, last accessed on: 02.04.2017.

Cristi Dănileț, "The doctor is liable in the same way as a civil servant if he commits corruption offenses", August 17, 2015. Source: http://www.contributors.ro/ administratie/medicul-raspunde-la-fel-ca-un-functionar-public-daca-comiteinfractiuni-de-coruptie/, last accessed on: 25.09.2016.

Avocatnet.ro, "HCCJ Decision no. 19/2015 - doctors who are civil servants cannot receive additional payments or donations", August 7, 2015. Source: http://www.avocatnet.ro/content/articles/id_41160/Decizia-HCCJ-nr-192015-medicii-care-au-calitatea-de-functionar-public-nu-pot-primi-platisuplimentare-sau- donatii.html, last accessed on: 21.09.2016.

Valentina Postelnicu, "President Băsescu promulgated the law removing doctors from thecategory of civil servants", October 8, 2014. Source:

http://www.mediafax.ro/social/presedintele-basescu-a-promulgat-legeacare-scoate-medicii-din-categoria-functionarilor-publici-13372495, last accessed on: 18.09.2016.

Elvira Gheorghiță, "CPR against the HCCJ decision: Doctors are not civil servants, the legislation allows donations", August 14, 2015. Source: https://www.mediafax.ro/social/cmr-fata-de-decizia-HCCJ-medicii-nu-suntfunctionari-publici-legislatia-permite-donatii-14675821.

Formaremedicala.ro, "Doctors do not give up. The doctors' alliance declined the Government's invitation to participate in the talks ", August 18, 2015. Source: https://www.formaremedicala.ro/medicii-nu-cedeaza-alianta-declinat-invitatia guvernului-de-a-participa-la-discutii/, last accessed on: 24.09.2016.

Digi24.ro, "What does the envelope for doctors contain and why do patients not give it up", July 9, 2016 http://www.digi24.ro/stiri/actualitate/social/ce-contineplicul-pentru-medici-si-de-ce-nu-renunta-pacientii-la-el-540153, last accessed on: 20.09.2016.

Digi 24.ro, "Sorina Pintea, sent to court for taking bribes". April 30, 2020. Source: https://www.digi24.ro/stiri/actualitate/justitie/sorina-pintea-trimisa-injudecata-pentru-luare-de-mita-1299828, last accessed on: 22.04.2021.

EuropaFM.ro, "Europa FM Barometer: Do Romanians Trust State Hospitals? Do they agree with the optional increase of the retirement age? ", February 3, 2020. Source: https://www.europafm.ro/barometru-europa-fm-au-incredere-romaniiin-spitalele-de-stat-sunt-de-acord-cu-majorarea-optionala-a-varstei-depensionare/?fbclid=IwAR337096pj6XjZjc2RMuMdYqXJLVnHW1xPIYlXTSvP_ KM6N6rbrXTo1Hkn8, last accessed on: 22.04.2021. 
Alina Mihai, "Renate Weber explains why hospitals are being monitored by the Romanian Ombudsman for 'prevention of torture or treatment specific to places of detention'”, June 11, 2020. Source: https://www.mediafax.ro/ social/renate-weberexplica-de-ce-spitalele-sunt-monitorizate-de-avocatul-poporului-pentru-prevenirea-torturii-ori-tratamente-specifice-locurilor-de-detentie-19275263, last accessed on: 28.05.202.

Dan Tăpălagă, "Who are these rioters?", March 31, 2021. Source:

https://www.g4media.ro/cine-sunt-acesti-revoltati.html, last accessed on: 29.05.2021.

Răzvan Căucean, "Doctors' reaction to protests in front of hospitals: "From heroes we became torturers and assassins", March 31, 2021. Source:

https://dej24.ro/reactia-medicilor-la-protestele-din-fata-spitalelor-am-ajunsdin-eroi-tortionari-si-asasini/, last accessed on 29.05.2021.

G4Media.ro, "Nelu Tătaru, about the fire in Piatra Neamț: We are all guilty because we accepted 30 years to live in such a medical situation", November 15, 2020. Source: https://www.g4media.ro/nelu-tataru-suntem-toti-vinovati-ca-am-acceptat-30-de-ani-sa-traim-intr-o-astfel-de-situatie-medicala.html, last accessed on: 29.05.2021.

\section{REFERENCES}

Adloff, F. (2006). Beyond Interests and Norms: Gift-giving and Reciprocity in Modern Societies. In Constellations: An International Journal of Critical and Democratic Theory, 13(2):407-442.

Appadurai, A. (1986). The Social Life of Things: Commodities in Cultural Perspective. Cambridge: Cambridge University Press, pp. 3-61 (On-line: http://assets.cambridge.org, last access: 07.03.2021).

Bell, D. (1991). Modes of Exchange: Gift and Commodity. In The Journal of SocioEconomics, 20(2):155-167.

Balabanova, D., McKee, M. (2002) Understanding Informal Payments for Health Care: The example of Bulgaria. In Health Policy, 62: 243-73.

Belli, P., Gotsadze, G., Shahriari, H. (2004). Out-of-Pocket and Informal Payments in Health Sector: Evidence from Georgia. In Health Policy, 70: 109-123.

Bourdieu, P. (1977). Outline of a Theory of Practice. Cambridge: Cambridge University Press.

Bourdieu, P. (1984). Distinction: A Social Critique of the Judgment of Taste. London: Routledge.

Bourdieu, P. (2012). Limbaj și putere simbolică. București: Editura Art, pp. 135-163; 175-278. Ensor, T., Savelyeva L. (1998). Informal Payments for Health Care in the Former Soviet Union: Some Evidence from Kazakstan. In Health Policy and Planning, 13(1): 41-49.

Ensor, T. (2004). Informal Payments for Health Care in Transition Economies. In Health Policy, 58 (2): 237-246. 
Gaal, P., Evetovits, T., McKee, M. (2006). Informal Payment for Health Care: Evidence from Hungary. In Health Policy, 77(1):86-102.

Gregory, C. (1997). Savage Money: The Anthropology and Politics of Commodity Exchange. Amsterdam: Harwood Academic.

Gregory, C. (1982). Gifts and Commodities. London: Academic Press.

Lambertini, L., Scarpa, C. (1999). Minimum Quality Standards and Predatory Behaviour, Nota di Lavoro, No. 86.1999, Fondazione Eni Enrico Mattei (FEEM), Milano (On-line: https://www.econstor.eu/handle/10419/155039, last access: 14.06.2021).

Lewin, H., Morris, J. (1977). Marx's Concept of Fetishism. In Science \& Society, 41(2): 172-190.

Lewis, M. (2000). Who is Paying for Health Care in Eastern Europe and Central Asia? Washington: The International Bank for Reconstruction and Development, pp.12-34 (On-line: https://papers.ssrn.com/sol3/papers.cfm?abstract_id= 1457795 , last access on 16.03.2020).

Lewis, M. (2006). Governance and Corruption in Public Health Care Systems. In Center for Global Development - Working Paper 78 (On-line: http://www.cgdev.org).

Liaropoulos L., Siskou, O., Kaitelidou D., Theodorou M. (2008). Informal Payments in Public Hospitals in Greece. In Health Policy, 87: 72-81.

Lomnitz, L. A. (1988).Informal Exchange Networks in Formal Systems: A Theoretical Model. In American Anthropologist, 90(1), 42-55.

Mauss, M. (1990 [1925]). The Gift. The Form and Reason for Exchange in Archaic Societies. New York/London: W. W. Norton.

Marx, K. (2013 [1867]). Capital, Volume I. Capitalist Production, Part I: Commodities and Money, Chapter I: Commodities, Section IV: The Fetishism of Commodities and the Secret Thereof. Hertfordshire: Wordsworth Editions Limited, pp. 4655.

Najar, A.V., Ebrahimipour, H., Purtaleb, A., Esmaily, H., Jafari, M., Nejatzadegan, Z., Taleghani, Y.M. (2017). At first Glance, Informal Payments Experience on Track: Why Accept or Refuse? Patients' Perception in Cardiac Surgery Department of Public hospitals, Northeast of Iran. In BMC Health Services Research, 17(1): 205

Palaga, C. (2015).From Informal Exchanges to Dual Medical Practices. The Shadows of the Romanian Health Care Reform. In STUDIA UBB SOCIOLOGIA, LX(1): 103122.

Parry, J., Bloch, M. (1989). Introduction: money and the morality of exchange. In Money and the morality of exchange. Cambridge: Cambridge University Press, pp. 132.

Rus, A. (2008). 'Gift vs. Commodity' Debate revisited. In Anthropological Notebooks: 14(1):81-102 (On-line: http://www.drustvo-antropologov.si, last access: 12.07.2020).

Savedoff, W. D. (2006). The causes of corruption in the health sector: a focus on healthcare systems. In Transparency International. Global Corruption Report 2006: Special focus on corruption and health. London: Pluto Press. 
Sharma S., Smith S., Pine M., Winfrey W. (2005). Formal and Informal Reproductive Healthcare User Fees in Uttaranchal, India. Washington, DC: United States Agency for International Development.

Smart, A. (1993). Gifts, Bribes, and Guanxi: A Reconsideration of Bourdieu's Social. In Cultural Anthropology, 8(3): 388-408.

Stan, S. (2012). Neither Commodities nor Gifts: Post-socialist Informal Exchanges in the Romanian Healthcare System. In Journal of the Royal Anthropological Institute, 18:65-82.

Stepurko, T., Pavlova, M., Gryga, I., Groot, W. (2010). Empirical Studies on Informal Patient Payments for Health Care Services: A Systematic and Critical Review of Research Methods and Instruments. In BMC Health Services Research, 10, 273 (On-line: https://doi.org/10.1186/1472-6963-10-273, last access 12.05.2014).

Thompson, R., Witter, S. (2000). Informal Payments in Transitional Economies: Implications for Health Sector Reform. In International Journal of Health Planning and Management, 15: 169-187.

Vlădescu, C., Scîntee, G., Olsavssyky V. (2008). Romania. Health System Review. In Health Systems in Transition, 10(3): 1-172, pp. 21-80.

Williams, C., Horodnic, I.A., Horodnic, A.V. (2016). Who is Making Informal Payments for Public Healthcare in East-Central Europe? An Evaluation of Socio-economic and Spatial Variations. In Eastern Journal of European Studies, 7(1): 49-61.

Zerilli, F.M. (2013). Corruption and Anti-corruption Local Discourses and International Practices in Post-Socialist Romania. In Human Affairs, 23:212-229. 